\title{
Lithium and methylphenidate: opposite effects on perirenal brown fat
}

\author{
Lítio e metilfenidato: efeitos opostos sobre a gordura perirrenal
}

\author{
José Menna Oliveira, ${ }^{1}$ Leonardo Machado Crema, ${ }^{1}$ Luísa Amália Diehl, ${ }^{1}$ Letícia Ferreira Pettenuzzo, ${ }^{2}$ Liane \\ Tavares Bertinette, ${ }^{3}$ Carla Dalmaz, ${ }^{4}$ Elizabete Rocha da Rocha ${ }^{5}$
}

${ }^{1}$ Mestre em Neurociências, Universidade Federal do Rio Grande do Sul (UFRGS), Porto Alegre, RS, Brazil. Doutorando(a) em Neurociências, UFRGS. ${ }^{2}$ Doutora em Ciências Biológicas (Bioquímica), UFRGS. Bolsista, Programa Nacional de Pós-Doutorado, Coordenação de Aperfeiçoamento de Pessoal de Nível Superior (CAPES). ${ }^{3}$ Farmacêutica e bioquímica, Universidade Federal de Pelotas (UFPel), Pelotas, RS, Brazil. Estagiária, Programa de Pós-Graduação em Neurociências, UFRGS. ${ }^{4}$ Doutora em Ciências (Bioquímica), Universidade Federal do Paraná (UFPR), Curitiba, PR, Brazil. Professora adjunta IV, UFRGS. Bolsista de Produtividade em Pesquisa 1C, Conselho Nacional de Desenvolvimento Científico e Tecnológico (CNPq). Orientadora de Doutorado. ${ }^{5}$ Doutora em Ciências Biológicas (Bioquímica), UFRGS. Professora Adjunta IV, UFRGS.

Financial support: Conselho Nacional de Desenvolvimento Científico e Tecnológico (CNPq), Coordenação de Aperfeiçoamento de Pessoal de Nível Superior (CAPES), Financiadora de Estudos e Projetos (FINEP).

\begin{abstract}
Objective: To evaluate the effects of the administration of lithium to adult rats on brown (perirenal) and white (inguinal) adipose tissues and to assess whether methylphenidate modulates lithium effects.

Methods: Twenty-five adult male Wistar rats were fed with either regular or lithium-containing chow for 30 days. Between days 15 to 30 of treatment, animals received daily intraperitoneal administrations of either methylphenidate or saline.

Results: Lithium significantly reduced perirenal fat, and this effect was minimized by the administration of methylphenidate. There were no significant differences between the groups in terms of the effects of lithium on inguinal fat.

Conclusion: Our findings suggest that different effects on white and brown tissue distribution may be involved in lithium-induced weight gain.

Keywords: Lithium, methylphenidate, weight gain, obesity.
\end{abstract}

\section{Resumo}

Objetivo: Avaliar como a administração de lítio afeta o tecido adiposo marrom (perirrenal) e branco (inguinal) e se o metilfenidato modula os efeitos do lítio.

Métodos: Vinte e cinco ratos Wistar adultos machos foram alimentados com ração normal ou contendo lítio por 30 dias. Entre os dias 15 e 30 de tratamento, os animais receberam doses intraperitoneais diárias de metilfenidato ou solução salina.

Resultados: A administração de lítio reduziu significativamente a gordura perirrenal. Esse efeito foi reduzido com a administração de metilfenidato. Não houve diferenças significativas entre os grupos em relação à gordura inguinal.

Conclusão: Os achados sugerem que efeitos diferenciados sobre os tecidos adiposos marrom e branco podem estar envolvidos no ganho de peso induzido pelo tratamento com lítio.

Descritores: Lítio, metilfenidato, ganho de peso, obesidade.

Correspondence:

José Menna Oliveira, Departamento de Bioquímica, Instituto de Ciências Básicas da Saúde, UFRGS, Rua Ramiro Barcelos, 2600 (Anexo), Lab. 37 , CEP 90035-003, Porto Alegre, RS, Brazil. Tel./Fax: +55 (51) 3308.5569. E-mail: josemennaoliveira@gmail.com

No conflicts of interest declared concerning the publication of this article.

Copyright (C) Revista de Psiquiatria do Rio Grande do Sul - APRS 


\section{Introduction}

In the abdomen of mammals, brown and white adipose tissues (BAT and WAT, respectively) are distinctly located and have different, complementary functions: BAT is predominantly found in the perirenal tissue and mobilizes accumulated energy (e.g. heat) in response to noradrenergic stimulation; WAT occupies the inguinal tissue and mobilizes lipid reservoirs in response to metabolic needs between meals. ${ }^{1,2}$ There is adequate evidence of a regulatory role of BAT on WAT, as demonstrated by genetic studies in which impaired BAT activity has been associated with obesity, hyperlipidemia, and insulin resistance. ${ }^{3}$

Weight gain is a common side effect of lithium therapy in humans, ${ }^{4}$ but the mechanisms of this effect are not well established. ${ }^{5}$ Cell-culture studies with adipocyte precursors demonstrate an inhibitory effect of lithium on the differentiation of white ${ }^{6}$ and brown ${ }^{7}$ adipocytes.

The aims of the present study were: 1) to evaluate whether the administration of lithium to adult rats is able to independently modify perirenal (BAT) and inguinal (WAT) tissues; 2) because BAT is under noradrenergic control, ${ }^{8}$ to assess whether methylphenidate (MPH), a dopaminergic and noradrenergic drug, is able to modulate lithium effects. MPH was chosen because attention-deficit and hyperactivity have recently been recognized as frequent comorbidities in bipolar patients, ${ }^{9}$ and the coprescription of both drugs (lithium and $\mathrm{MPH})$ is becoming common in clinical practice.

\section{Methods}

Twenty-five adult male Wistar rats, 90-120 days old, weighing 160-220 g, were used in the study. Animals were fed with either regular (10 rats) or lithium-containing (15 rats) chow, at $2.5 \mathrm{mg} \mathrm{LiCl}+17 \mathrm{mg} \mathrm{NaCl} / \mathrm{g}$ of chow, as described previously, ${ }^{10}$ for 30 days. The lithium treatment delivered leads to serum levels between 0.4 and $1.2 \mathrm{mEq} / 1{ }^{11}$

Between days 15 to 30 of treatment, all animals in both groups received daily intraperitoneal administrations of a solution containing either MPH at $5 \mathrm{mg} / \mathrm{kg}$ (13 rats, of which eight had received lithium) or saline solution (12 rats, of which seven had received lithium), a regimen frequently employed in experiments performed with rats. ${ }^{12,13}$

On the 30th day of treatment, animals were decapitated, and perirenal and inguinal fat pads were dissected and weighed, using a scale with a precision of $0.0001 \mathrm{~g}$.

All treatments were in accordance with the guidelines of the institution where the study was carried out and followed the principles and recommendations of laboratory animal care. Data were analyzed using two-way analysis of variance (ANOVA), and results were expressed as mean \pm standard error of the mean (SEM).

\section{Results}

Lithium administration decreased animal weight $\left(\mathrm{h}^{2}=\right.$ 0.49 ), and MPH counterbalanced this effect $[\mathrm{F}(1,25)=6.94$, $\left.\mathrm{p}=0.01, \mathrm{~h}^{2}=0.11\right)$ as a result of the interaction between lithium and MPH. Figure 1 shows the effect of lithium and MPH on abdominal fat.

Lithium significantly reduced total abdominal fat $[\mathrm{F}(1,25)=$ $\left.7.19, \mathrm{p}=0.01, \mathrm{~h}^{2}=0.26\right]$, and MPH administration counteracted this effect, e.g. a significant interaction between lithium and MPH was observed $\left[\mathrm{F}(1,25)=5.24, \mathrm{p}=0.03, \mathrm{~h}^{2}=0.20\right]$. Perirenal fat was reduced by chronic lithium administration $[\mathrm{F}(1,25)=5.90$, $\left.\mathrm{p}=0.02, \mathrm{~h}^{2}=0.22\right]$, and this effect was significantly minimized by $\mathrm{MPH}\left[\mathrm{F}(1,25)=6.15, \mathrm{p}=0.02, \mathrm{~h}^{2}=0.23\right]$. With regard to inguinal fat, there were no significant differences between the groups, although a non-significant reduction was observed in lithium-treated animals $\left(\mathrm{p}=0.07, \mathrm{~h}^{2}=0.06\right)$.

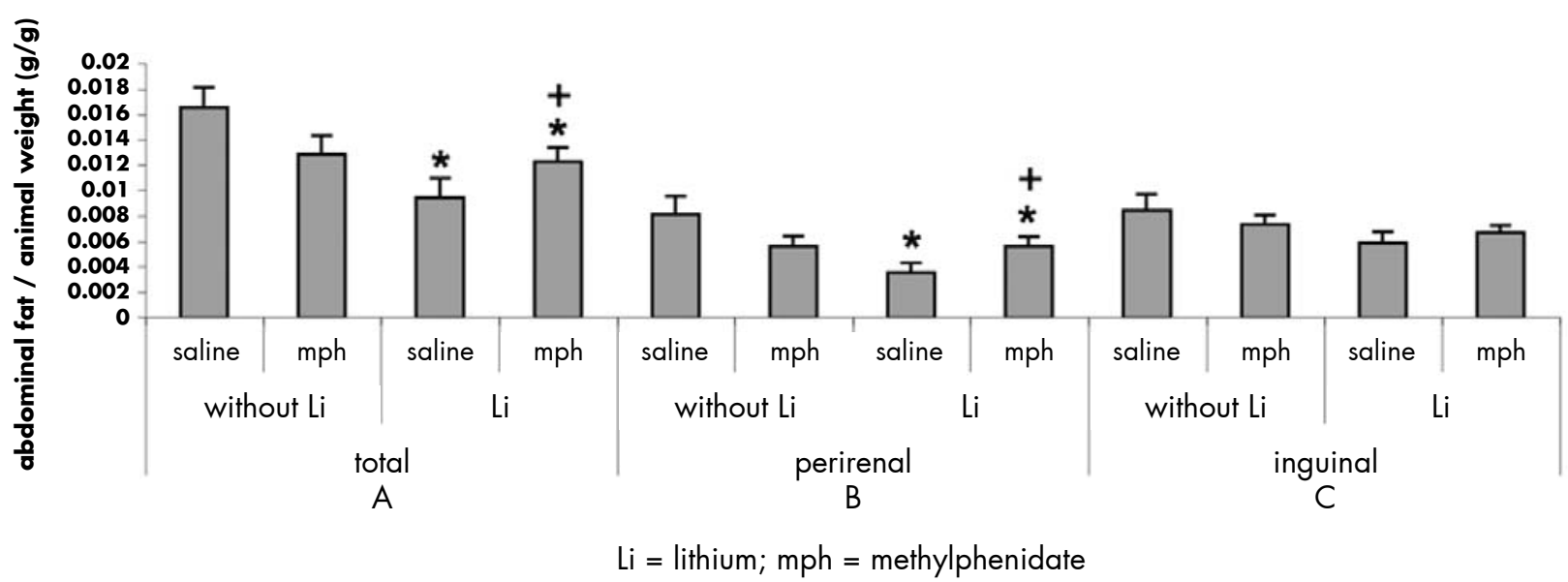

Figure 1 - Lithium and methylphenidate effects on abdominal fat. A) Total abdominal fat in relation to animal weight:

* lithium effect, $\mathrm{p}=0.01 ;+*$ lithium-methylphenidate interaction, $\mathrm{p}=0.03$. B) Perirenal fat in relation to animal weight:

* lithium effect, $\mathrm{p}=0.02 ;+*$ lithium-methylphenidate interaction, $\mathrm{p}=0.02$. C) Inguinal fat in relation to animal weight: no significant differences were found. 


\section{Discussion}

Our study showed that 30 days of lithium treatment reduced total and perirenal fat and that this effect was counterbalanced by MPH administration. To our knowledge, no other studies have so far been designed to evaluate the effects of lithium on perirenal and inguinal fat in vivo.

Previous studies with cell cultures have shown that lithium inhibits adipocyte differentiation: inducer-stimulated adipose conversion of 3T3-L1 cells was inhibited by lithium in mouse preadipocyte models, ${ }^{6}$ as was the expression of mRNAs for UCP-1, PG-1 alpha, and PPAR-alpha, genes that are specific to differentiated brown tissue. ${ }^{7}$ The process seems to occur via inhibition of GSK-3 $\beta$, and hence, indirectly, enhancement of transmission via the Wnt signaling pathway. ${ }^{14,15}$

A reduction in BAT may be explained by decreased synthesis or increased degradation of triacylglycerol depots. BAT stimulation occurs mainly via beta-adrenergic receptors and the cAMP signal transduction pathway, and there are well documented effects of lithium on the noradrenaline pool, on the expression of adrenoceptors, on Gs- and Gi-proteins, and on adenyl cyclase function. ${ }^{5,16}$ This may, at least in part, explain our results. Also, lithium-related inhibition of GSK$\beta$ and the consequent enhancement of Wnt signaling may underlie the effects herein observed on fat stores.

The counterbalance provided by MPH against the effects of lithium is in accordance with the already known noradrenergic stimulation of BAT. MPH inhibits noradrenaline and dopamine transporters at a $\mathrm{K}_{\mathrm{I}}$ of $0.17 \pm 0.03$ and $0.26 \pm 0.03 \mathrm{mcM}$, respectively. ${ }^{17}$ The administration of noradrenaline to cells whose differentiation was inhibited by $5 \mathrm{mM}$ of lithium as of the 4th day of culture has led to UCP-1 mRNA expression, a characteristic of active BAT. ${ }^{7}$

However, although our results are in accordance with the reported literature, some relevant considerations should be made. First, treatment effect sizes in this study were small, and data should be analyzed under this perspective. Second, the effects on cell differentiation observed in cell cultures are not the same observed in adult tissues. In fact, a previous study has described that, on the seventh day of culture, when cells are already differentiated, lithium treatment does not modify cells. ${ }^{\text {? }}$

The inhibitory effect of lithium on cell differentiation and also, according to our results, on fat mass (BAT in particular) seems to be a paradox in light of the known weight gain associated with lithium treatment in humans. There are some possible explanations to this finding. First, in great mammals, including humans, the amount of BAT decreases importantly after birth, whereas in rodents it persists throughout life ${ }^{1}$; this may contribute to inter-species differences in terms of BAT/WAT regulation and lithium treatment effects. Second, it is possible that differences in the texture or palatability of the chows administered to rats have modified consumption patterns, although a previous experiment using normal chow prepared with $\mathrm{NaCl}$ in the same concentrations used in the present study did not affect consumption (Vasconcellos APS, personal communication), and another study by the same group of authors currently under development performed with animals receiving the same lithium-containing chow reported that these animals ate more normal chow and highcaloric foods when compared with controls. Also, genetic manipulations in which BAT features are underexpressed have been found to cause obesity and insulin resistance. ${ }^{18}$ Because obesity does not occur suddenly, it is possible that differences in inguinal fat would be observed had the animals been followed over a longer period. This long-term assessment, however, is a matter for future studies.

\section{References}

1. Hansen JB, Kristiansen K. Regulatory circuits controlling white versus brown adipocyte differentiation. Biochem J. 2006;398:153-68.

2. Cannon B, Nedergaard J. Brown adipose tissue: function and physiological significance. Physiol Rev. 2004;84:277-359.

3. Lowell BB, Susulic VS, Harmann A, Lawitts JA, Himms-Hagen J, Boyer BB, et al. Development of obesity in transgenic mice after genetic ablation of brown adipose tissue. Nature. 1993;366:740-2.

4. Garland EJ, Remick RA, Zis AP. Weight gain with antidepressants and lithium. J Clin Psychopharmacol. 1988;8:323-30.

5. Lenox RH, Manji HK. Lithium. In: Schatzberg AF, Nemeroff CB, editors Textbook of psychopharmacology. 2nd ed. Washington: The American Psychiatric Press; 1998. p. 379-429.

6. Aratani Y, Sugimoto E, Kitagawa Y. Lithium ion reversibly inhibits inducerstimulated adipose conversion of 3T3-L1 cells. FEBS Lett. 1987;218:47-51.

7. Rodríguez de la Concepción ML, Yubero P, Iglesias R, Giralt M, Villarroya F. Lithium inhibits brown adipocyte differentiation. FEBS Lett. 2005;579:1670-4.

8. Avram AS, Avram MM, James WD. Subcutaneous fat in normal and diseased states: 2. Anatomy and physiology of white and brown adipose tissue. J Am Acad Dermatol. 2005;53:671-83.

9. Tamam L, Karakus G, Ozpoyraz N. Comorbidity of adult attention-deficit hyperactivity disorder and bipolar disorder: prevalence and clinical correlates. Eur Arch Psychiatry Clin Neurosci. 2008;258:385-93

10. Vasconcellos AP, Tabajara AS, Ferrari C, Rocha E, Dalmaz C. Effect of chronic stress on spatial memory in rats is attenuated by lithium treatment. Physiol Behav. 2003;79:143-9.

11. Rocha E, Rodnight R. Chronic administration of lithium chloride increases immunodetectable glial fibrillary acidic protein in the rat hippocampus. $\mathrm{J}$ Neurochem. 1994;63:1582-4.

12. Cassaday HJ, Finger BC, Horsley RR. Methylphenidate and nicotine focus responding to an informative discrete $\mathrm{CS}$ over successive sessions of appetitive conditioning. J Psychopharmacol. 2008;8:849-59.

13. Duchin D, Taukulis HK. Chronic oral methylphenidate administration to periadolescent rats yields prolonged impairment of memory for objects. Neurobiol Learn Mem. 2007;88:312-20.

14. Ross SE, Hemati N, Longo KA, Bennett CN, Lucas PC, Erickson RL, et al. Inhibition of adipogenesis by Wnt signaling. Science. 2000;289:950-3.

15. Zaragosi LE, Wdziekonski B, Fontaine C, Villageois P, Peraldi P, Dani C. Effects of GSK3 inhibitors on in vitro expansion and differentiation of human adiposederived stem cells into adipocytes. BMC Cell Biol. 2008;9:11.

16. Jope RS. Anti-bipolar therapy: mechanism of action of lithium. Mol Psychiatry. 1999;4:117-28.

17. Han DD, Gu HH. Comparison of the monoamine transporters from human and mouse in their sensitivities to psychostimulant drugs. BMC Pharmacol. 2006;6:6.

18. Yang X, Enerback S, Smith U. Reduced expression of FOXC2 and brown adipogenic genes in human subjects with insulin resistance. Obes Res. 2003;11:1182-91. 